\title{
Analysis of the Influence of Capital Structure and Profit Ability on Corporate Value: Empirical Study with Modigliani and Miller Theory of Investment Review
}

\author{
Jojor Lisbet Sibarani \\ Politeknik Negeri Medan \\ Cahyo Ginarti \\ Politeknik Negeri Medan \\ Rosmaida Tambun \\ Politeknik Negeri Medan \\ Meily Surianti \\ Politeknik Negeri Medan
}

\begin{abstract}
This study aims to provide empirical evidence of the influence of capital structure and profitability on firm value. The selection of independent variables capital structure and profitability to prove the proposition Modigliani and Miller (1958) which states that the value of the company is not influenced by capital structure, but rather influenced by profitability. The results of this study are expected to provide insight and understanding of capital market behavior in Indonesia, particularly those relating to decision making by investors. The contribution of research results is to the field of accounting especially the subject of financial accounting and the subject of investment and portfolio management is the field of science that gets the most contribution from this research. The results of this study can also be used as learning material for the course concerned. The research method used is descriptive quantitative, using multiple regression analysis, using secondary data from LQ 45 companies listed on the Indonesia Stock Exchange. hypothesis testing does not support the Modigliani and Miller (1958) hypotheses, which maintain market efficiency and symmetrical assumptions of information and state that capital structure will not affect firm value
\end{abstract}

Keywords: capital structure, profitability, company value, LQ 45

DOI: $10.7176 / \mathrm{EJBM} / 12-3-20$

Publication date: January $31^{\text {st }} 2020$

\section{Background of Study}

Capital structure is part of the financial structure that reflects the ratio (absolute or relative) between all external capital (both short-term and long-term) with total capital (Riyanto, 1999). Companies that are expected to grow high in the future tend to use shares to finance their operational activities. Conversely, for this reason companies with low growth opportunities usually use long-term debt as a source of their financing. Because growth opportunities vary between companies, their financing decisions, management will also vary. Companies with good growth opportunities tend to use their own capital to avoid underinvestment; a condition in which a positive value investment project fails to be implemented, (Chen, 2004).

This study seeks to prove the proposition of Modigliani and Miller (1958) by examining the effect of capital structure and profitability on firm value. Research that seeks to obtain empirical evidence about the relationship between capital structure and firm performance (firm value) remains divided. Several studies found this relationship to be negative (Mykhailo, 2013 and Akeem et al, 2014 etc.). In contrast, several other studies have found a positive relationship between capital structure and firm performance (firm value) such as Kaplan (1989), Smith (1990), Ogbulu \& Emeni (2012) and Akinyomi \& Olagunju, (2014).

This research will be conducted on LQ 45 companies listed on the Jakarta Stock Exchange. LQ 45 is the most liquid company in trading on the stock market. The LQ 45 company was chosen because the companies that are liquid in trade are the companies that get the most attention from investors, so this test is expected to contribute more from the perspective of investor decision making. 


\section{Literature Review}

\section{Modigliani and Miller Theory of Investment}

In financial theory, the debate over capital structure continues to produce a lot of controversy, and has not yet been resolved. Modigliani and Miller (1958) assert that given the Arrow-Debreu market assumption, without market friction, the capital structure used by a company is irrelevant to its value or financial performance. The famous Modigliani-Miller Proposition that the value of a company depends on its profitability and not on its capital structure is recognized as an application to the financial doctrine that money is neutral.

Modigliani and Miller (1958) in their article entitled "The Cost of Capital, Corporate Finance and Theory of Investment" explains the fact that modern financial business theory starts with the proposition of irrelevance in capital structure Modigliani and Miller (1958) have tried in their paper to answer questions related to corporate finance.

Bose (2010) provides further explanation about Modigliani and Miller's assumptions. According to Bose (2010), Modigliani and Miller argue that in the same level of risk, there is no effect of capital costs in the case of debtequity changes. The observations of Modigliani and Miller in their 1958 article and illustrated by Bose (2010) as "There is no dependency between the value of the company and the cost of capital of the company to its capital structure".

\section{Company Value}

One measure that indicates the size of a company's value is the size of the company's assets. The company has total assets which indicate that the company has reached the maturity stage where at this stage the company has a positive cash flow and is considered to have good prospects in a relatively long time, but also thus reflects that the company is relatively more stable and more able to generate profits than the company with small total assets (Daniati and Suhairi, 2006). Assets are a measure of the size or scale of a company. Usually, large companies have assets of greater value. Theoretically, larger companies have greater certainty than smaller companies that will reduce the level of uncertainty about the company's future prospects. This can help investors predict possible risks when investing in companies. The main goal of the company is to increase the value of the company through increasing the prosperity of the owner or shareholder.

One way to measure the value of a company is to use Tobin's Q. The Q ratio is the ratio of market to book value which is calculated from the market price ratio of the company's equity plus debt divided by the value of the company's assets. In addition to using Tobin "s Q, in assessing the value of the company can use the PBV (Price to Book Value) method.

\section{Capital Structure}

Capital structure refers to the amount of debt and / or equity used by a company to fund its operations and finance its assets. This structure is usually expressed as the ratio of debt to capital or debt to capital. Debt capital and equity are used to fund business operations, capital expenditure, acquisitions and other investments. There is a tradeoff that must be made by the company when they decide whether to increase debt or equity and the manager will balance the two trying and find the optimal capital structure.

The Corporate Finance Literature offers two schools of thought that explain the choice of the company's capital structure. The first school of thought is the trade-off theory, which suggests the existence of an optimal capital structure, by incorporating various imperfections into the capital market which is ignored by Modigliani and Miller's (1958) hypotheses, but maintains assumptions of market efficiency and symmetrical information. Thus, although increasing leverage can enable a firm to increase its value by taking advantage of the tax shield on debt (Modigliani and Miller, 1963)

\section{Profitability}

Profitability is the company's ability to generate profits and to measure the value of its own operational efficiency and the efficiency of using its own properties (Chen, 2004). According to Petronila and Mukhlasin (2003) profitability is a picture of management performance in controlling a company.

Profitability ratios can be measured from two approaches namely the sales approach and the investment approach. 
The most widely used measures are return on assets (ROA) and return on equity (ROE). ROA and ROE reflect business attractiveness (business interesting). Asset return (ROA) is a measure of a company's overall ability to generate profits with the total amount of assets available in the company. ROA is used to see the level of overall company operating efficiency. One measure of profitability ratios that is often used is return on equity (ROE), which is a measure of a company's ability to generate profits with its own total capital used. This ratio shows the efficiency of investment seen in the effectiveness of their own capital management.

\section{Research Methods}

This research is quantitative research. Quantitative research is a systematic scientific study of parts and phenomena and their relationships. The data collected is secondary data, which is derived from the financial statements of LQ 45 companies listed on the Indonesia Stock Exchange for the period 2009 - 2018. The measurement parameters used are:

\section{Company Value}

The way to measure company value is to use the Price to Book Value method, with the formula:

Price to Book Value $(\mathrm{PBV})=$ Stock Price per Share $/$ Book Value Per Share

\section{Capital Structure}

Capital structure refers to the amount of debt and / or equity used by a company to fund its operations and finance its assets. This structure is usually expressed as the ratio of debt to capital or debt to capital, with the formula:

DER $=$ Total Debt $/$ Total Capital x 100\%

\section{Profitability}

The profitability ratio that is often used is return on equity (ROE), which is a measure of a company's ability to generate profits with its own total capital used. This ratio shows the efficiency of investment seen in the effectiveness of their own capital management, which is written in the formula:

ROE $=$ Net Profit $/$ Total Equity

\section{Research Results}

\section{Classical Assumption Test}

Normality test

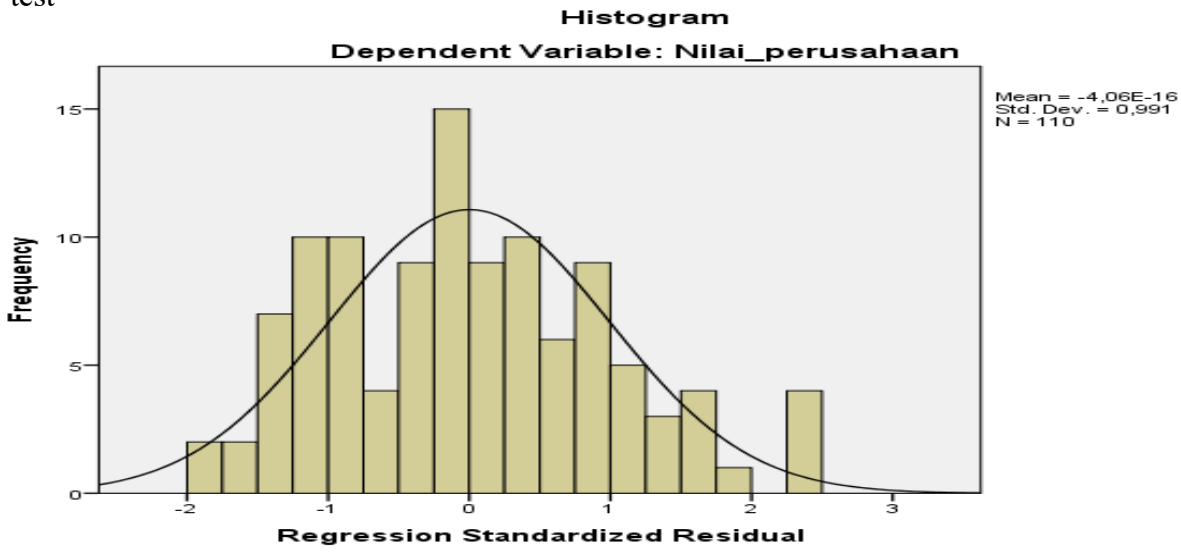

Figure 1. 


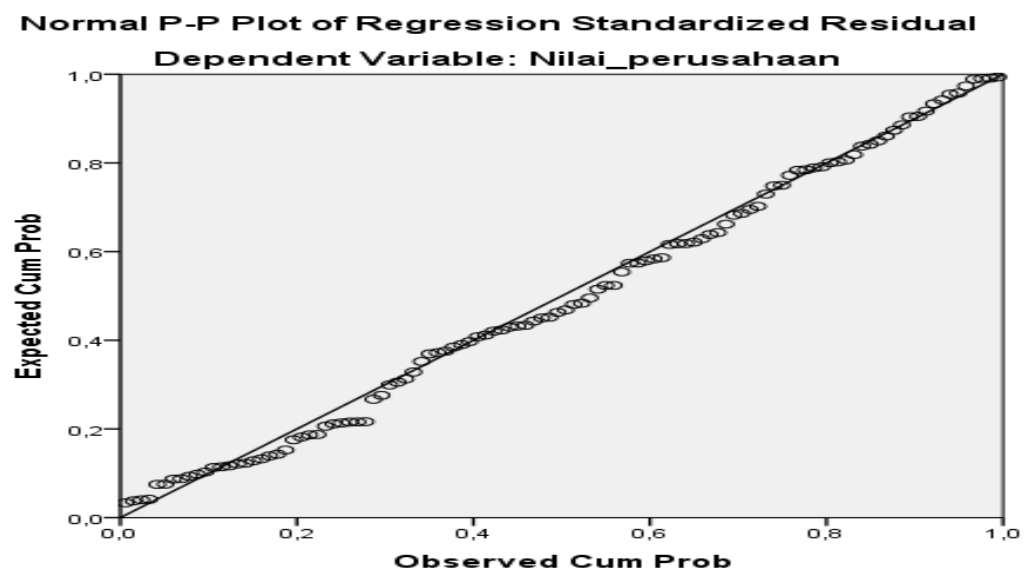

Figure 2.

From the histogram and p plot above, it can be seen that the research data are normally distributed.

Multicollinearity Test

\section{Coefficients $^{a}$}

\begin{tabular}{|ll|r|r|}
\hline \multirow{2}{*}{ Model } & \multicolumn{2}{|c|}{ Collinearity Statistics } \\
\cline { 3 - 4 } & & Tolerance & \multicolumn{1}{c|}{ VIF } \\
\hline 1 & Profitabilitas &, 999 & 1,001 \\
& Struktur_modal &, 999 & 1,001 \\
\hline
\end{tabular}

a. Dependent Variable: Nilai_perusahaan

Figure 3.

The results of the multicollinearity test show the VIF values of the three independent variables both $<10$. This means that there is no multicollinearity problem in the regression equation to be tested.

Heteroscedasticity Test

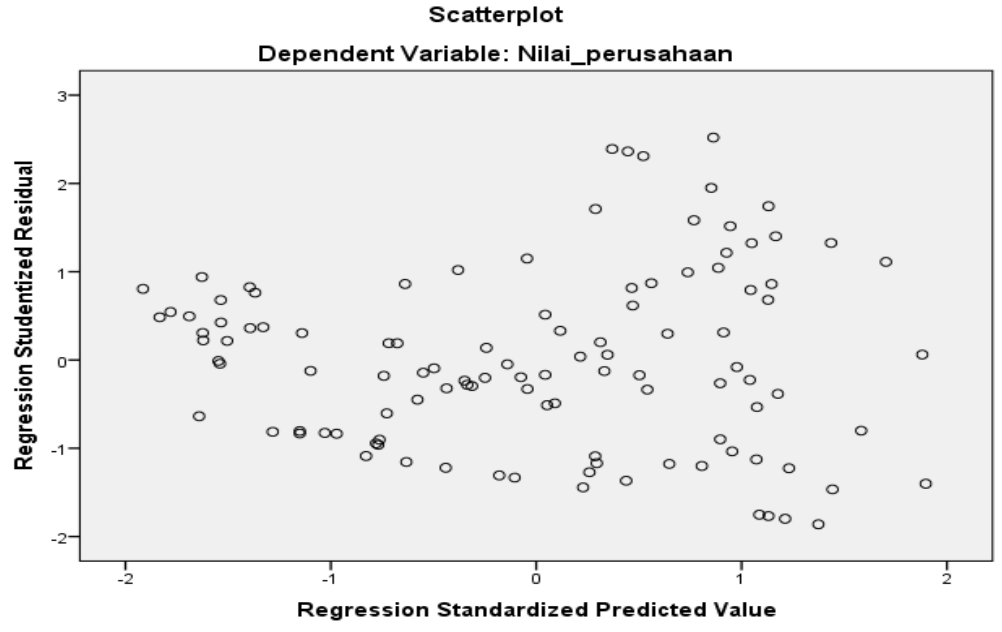

Figure 4. 
Autokoleration Test

Runs Test

\begin{tabular}{|l|r|r|r|}
\hline & Profitabilitas & $\begin{array}{c}\text { Struktur_mod } \\
\text { al }\end{array}$ & $\begin{array}{c}\text { Nilai_perusah } \\
\text { aan }\end{array}$ \\
\hline Test Value $^{\text {a }}$ &, 18 &, 75 & 1,79 \\
Cases < Test Value & 49 & 55 & 55 \\
Cases >= Test Value & 61 & 55 & 55 \\
Total Cases & 110 & 110 & 110 \\
Number of Runs & 51 & 50 & 66 \\
Z &,- 843 & $-1,149$ & 1,916 \\
Asymp. Sig. (2-tailed) &, 399 &, 250 &, 055 \\
\hline
\end{tabular}

a. Median

Figure 5.

Statistical Test Results

Descriptive statistics

Descriptive Statistics

\begin{tabular}{|l|r|r|r|r|r|r|r|}
\hline & \multicolumn{1}{|c|}{$\mathrm{N}$} & \multicolumn{1}{|c|}{ Range } & Minimum & Maximum & \multicolumn{1}{c|}{ Mean } & Std. Deviation & Variance \\
\hline Profitabilitas & 110 &, 38 &, 00 &, 38 &, 1858 &, 07830 &, 006 \\
Strukkur_modal & 110 & 8,41 &, 02 & 8,43 & 1,8974 & 2,46820 & 6,092 \\
Nilai_perusahaan & 110 & 6,14 &, 00 & 6,14 & 2,0038 & 1,55129 & 2,406 \\
Valid N (listwise) & 110 & & & & & & \\
\hline
\end{tabular}

Figure 6.

Multiple Regression Results

Variables Entered/Removed ${ }^{a}$

\begin{tabular}{|l|l|l|l|}
\hline Model & \multicolumn{1}{|c|}{$\begin{array}{c}\text { Variables } \\
\text { Entered }\end{array}$} & $\begin{array}{c}\text { Variables } \\
\text { Removed }\end{array}$ & \multicolumn{1}{|c|}{ Method } \\
\hline 1 & $\begin{array}{l}\text { Struktur_mod } \\
\text { al, } \\
\text { Profitabilitas }^{\text {b }}\end{array}$ & & Enter \\
\hline
\end{tabular}

a. Dependent Variable: Nilai_perusahaan

b. All requested variables entered.

Figure 7.

Model Summary ${ }^{\mathrm{b}}$

\begin{tabular}{|l|c|r|r|r|}
\hline Model & R & R Square & $\begin{array}{c}\text { Adjusted R } \\
\text { Square }\end{array}$ & $\begin{array}{c}\text { Std. Error of } \\
\text { the Estimate }\end{array}$ \\
\hline 1 &, $332^{\text {a }}$ &, 110 &, 094 & 1,47687 \\
\hline
\end{tabular}

a. Predictors: (Constant), Struktur_modal, Profitabilitas

b. Dependent Variable: Nilai_perusahaan

Figure 8. 
ANOVA $^{a}$

\begin{tabular}{|c|c|c|c|c|c|c|}
\hline Model & & $\begin{array}{l}\text { Sum of } \\
\text { Squares }\end{array}$ & df & Mean Square & $\mathrm{F}$ & Sig. \\
\hline \multirow[t]{3}{*}{1} & Regression & 28,927 & 2 & 14,464 & 6,631 &, $002^{b}$ \\
\hline & Residual & 233,381 & 107 & 2,181 & & \\
\hline & Total & 262,308 & 109 & & & \\
\hline
\end{tabular}

a. DependentVariable: Nilai_perusahaan

b. Predictors: (Constant), Struktur_modal, Profitabilitas

Figure 9.

\begin{tabular}{|c|c|c|c|c|c|c|}
\hline \multicolumn{7}{|c|}{ Coefficients $^{\mathrm{a}}$} \\
\hline \multirow[b]{2}{*}{ Model } & & \multicolumn{2}{|c|}{ Unstandardized Coefficients } & $\begin{array}{l}\text { Standardized } \\
\text { Coefficients }\end{array}$ & \multirow[b]{2}{*}{$t$} & \multirow[b]{2}{*}{ Sig. } \\
\hline & & B & Std. Error & Beta & & \\
\hline \multirow[t]{3}{*}{1} & (Constant) & 1,488 &, 384 & & 3,880 &, 000 \\
\hline & Profitabilitas & 4,328 & 1,808 &, 218 & 2,394 &, 018 \\
\hline & Struktur_modal &,- 152 &, 057 & -242 & $-2,655$ &, 009 \\
\hline
\end{tabular}

a. Dependent Variable: Nilai_perusahaan

Figure 10.

Discussion

\section{Adjusted R Square}

From the table of statistical test results, Adjusted R Square shows the value of 0.094. Adjusted R Square value of 0.094 means that the independent variables can explain the dependent variable by $9.4 \%$, while the remaining $90.6 \%$ is explained by other variables. The table also shows the results of the $\mathrm{F}$ test which showed a significance value of 0.002 . Value $0.002<0.05$, which means that the linear regression model can be used to predict the effect of independent variables namely profitability and capital structure on the dependent variable of firm value, at the level of significance 0.05 .

\section{Hypothesis Test Results}

Hypothesis test results indicate the value of the sign. $t$ profitability variable is 0.018 . Value of $0.018<0.05$, which means that the profitability variable influences the company's value variable. While the sign coefficient. $t$ of the capital structure variable, showing a value of 0.009 , where this value $<0.05$, in other words the capital structure variable influences the firm's value. The results of this hypothesis test apparently do not support the Modigliani and Miller (1958) hypothesis, which still maintains the assumption of market efficiency and symmetrical information and states that capital structure will not affect the value of the company while the Trade Off Theory states that management will determine the optimal debt and equity ratio for maximize the performance / value of the company.

\section{Conclusions and Suggestions}

From the results of statistical tests and hypothesis tests, it can be seen that the profitability and capital structure variables are only able to explain $9.4 \%$ of the company's value variables. In addition, hypothesis testing does not support the Modigliani and Miller (1958) hypotheses, which maintain market efficiency and symmetrical assumptions of information and state that capital structure will not affect firm value 
Based on the conclusions above, it is recommended for future research, in order to expand the population, increase the number of samples, and increase the span of the observation period.

\section{Reference}

Akeem, L. B., Edwin. T., Kiyanjui, M. W. \& Kayode, A. M. 2014. Effects of capital structure on Firm's performance: Empirical study of manufacturing study in Nigeria. Journal of Finance and Investment analysis, vol. 3 no. 4 pp. 39-57.

Akinyomi, O.J. \& Olagunju, A. 2013. Determinants of capital structure in Nigeria. International Journal of Innovation and Applied Studies vol. 3 no. 4 pp. 999-1005.

Ang, Robert. 1997. Buku Pintar Pasar Modal Indonesia. Jakarta: Mediasoft Indonesia

Bose, C. 2010. Fundamentals of Financial Management (2nd edition ed.). New Delhi, India: Asoke K. Ghosh, PHI Learning Private Limited.

Chen, K. 2002. The influence of capital structure on company value with different growth opportunities. working paper, EFMA 2002 London Meetings.

Daniati, Ninna; Suhairi, 2006. Pengaruh Kandungan Informasi Komponen Arus Kas, Laba Kotor dan Size Perusahaan Terhadap Expected Return Saham Pada Industri Textile dan Automotive yang Terdaftar di BEJ. Simposium Nasional Akuntansi 9 Padang.

Fakhruddin, M. dan M.S. Hadianto. 2001. Perangkat dan Model Analisis Investasi di Pasar Modal. Jakarta: Elex Media Komputindo.

Jensen, M.C. \& Meckling, W.H. 1976. Theory of the firm: Managerial behaviour, agency costs and ownership structure. Journal of Financial Economics, vol. 3 no. 4 pp. $305-360$.

Kaplan, S. 1989. The effects of management buyouts on operating performance and value. Journal of Financial Economics, vol. 24 no. 2 pp. $217-254$.

Luigi, P., \& Sorin, V. 2011. A Review Of The Capital Structure Theorie. Retrieved Sep 2011, From Ims Academic Research Network: Http://Khurambukhari.Files.Wordpress.Com/2011/02/000 14.Pdf

Mas'ud, M. 2008. Faktor-faktor penentu struktur Modal serta Dampaknya terhadap Nilai Perusahaan. Disertasi Program Doktor, Universitas Brawijaya, Malang. Tidak dipublikasikan.

Modigliani, F. and Miller, M. H. 1958. The cost of capital, corporate finance and the theory of investment. American Economic Review vol. 48, pp. $261-97$.

Modigliani, F. and Miller, M. H. 1963. Corporate income taxes and the cost of capital: a correction. American Economic Review vol. $53, p p .433-43$.

Myers, S. C. and Majluf, N. S. 1984. Corporate financing and investment decisions when firms have information that investors do not have. Journal of Financial Economics vol. 13, pp. 187 - 221.

Mykhailo, I. 2013. The impact of capital structure on firm performance: Evidence from Ukraine. MA Financial Economics Thesis Submitted to Kyiv School of Economics. Retrieved from www.kse.org.ua.

Ogbulu, O.M. \& Emeni, F.K. 2012. Capital structure and firm value: Empirical evidence from Nigeria. International Journal of Business and Social Science vol. 3 no. 19 pp. 252-26.

Petronila, Thio Anastasia dan Mukhlasin. 2003. Pengaruh Profitabilitas perusahaan terhadap Ketepatan Waktu Pelaporan Keuangan dengan Opini Audit Sebagai Moderating Variabel. Jurnal Ekonomi dan Bisnis Universitas Katolik Indonesia Atmajaya. Jakarta.

Riyanto, Bambang. 1999. Dasar-dasar Pembelanjaan Perusahaan, Edisi ke empat.: Yogyakarta: BPFE.

Ross, S. A., Westerfield, R. W. and Jaffe, J. F. 2002. Corporate Finance. Boston: McGraw-Hill/Irwin

Salvatore, Dominick. 2005. Ekonomi Manajerial dalam Perekonomian Global. Salemba Empat: Jakarta.

Schoubben, F., dan C. Van Hulle. 2004. The Determinant of Leverage: Difference beetwen Quoted and Non Quoted Firm. Tijdschriftvoor Economie en Management, vol. XLIX no. 4 pp. 589-621.

Smith, A.J. 1990. Corporate ownership structure and performance: The case of management buyouts. Journal of Financial Economics, vol. 27 no. 1 pp. $143-164$.

Sujoko dan U. Soebiantoro. 2007. Pengaruh Struktur Kepemilikan Saham, Leverage, Faktor Intern dan Faktor Ekstern terhadap Nilai Perusahaan. Jurnal Manajemen dan Kewirausahaan. vol. 9. no. 1 pp. 41-48.

Weston, J. Freddan Brigham, EF. 1998. Dasar-DasarManajemen Keuangan; Edisi Kesembilan, Jilid 2.

Weston, J.F. dan T.E. Copeland. 1997. Manajemen Keuangan, Edisi Kesembilan, terjemahan Jaka Wasana dan Kibrandoko, Jakarta: Binarupa Kasara, 